finished its report, which was being considered by the Select Committee this week. It should be published by the end of the session.

\section{Breach of Privilege}

Mr Tam Dalyell, a member of the Select Committee on Science and Technology, has been severely reprimanded by the House of Commons Committee of Privileges for passing on information about the Porton establishments. In a report published this week, the privileges committee says that Mr Dalyell was guilty of a serious breach of privilege and a serious contempt of the House; Mr Laurence Marks, Assistant News Editor of the Observer, who wrote the story about Porton, was also guilty of a contempt of the House, but the committee recommends that no action be taken against him. Mr David Astor, Editor of the Observer, was guilty of a more serious contempt, but again the committee recommends that no action should be taken.

The information given by $\mathrm{Mr}$ Dalyell to Mr Marks was contained in minutes of evidence taken by the Select Committee on a visit to Porton. Although these minutes had been published for the members of the committee, they were not generally available and the meeting at Porton had been private. Some of the material in the evidence would be "side-lined" (that is, deleted) before the evidence was officially published. Mr Dalyell gave it as his opinion that the proposed side-lining was "fatuous", but admitted that he was gravely at fault and offered profound apologies. $\mathrm{Mr}$ Marks said that he was unaware that a question of privilege arose, but he checked the story before publication with the $\mathrm{D}$ notice committee, which is responsible for clearing stories which may contain breaches of security. Admiral Denning of the D notice committee cleared the story for publication. As Mr Marks pointed out in evidence to the committee, it was not Admiral Denning's job to tell him the rules of parliamentary privilege.

The report of the committee draws one general moral from all this. The new committees, it says, rely for their success on the existence of mutual trust and confidence between their members and those who appear as witnesses, and breaches of this confidence may imperil their work.

The committee is within its rights, of course, to deal with members of the House of Commons as it chooseswhich is not to imply that it is right. But there must be serious doubts whether the committee is wise to try to bring the press to heel as well.

\section{Cheaper Water}

THE cost of supplying London with water in the seventies may have been cut by a system for upsetting the stratification of reservoir water which has been developed by the Metropolitan Water Board. Because of the tendency for water to stratify, especially during the summer when the demand for water is at a peak, deoxygenated and unusable water accumulates in the deeper layers with the result that reservoirs have had to be shallow and have had to cover large areas. Research at the Metropolitan Water Board's King George VI reservoir, where axial flow pumps have been used to break the summer epilimnion and hypolimnion stratification, has now, however, convinced the board that reservoirs 22 metres deep are an economic proposition; its existing reservoirs have a maximum depth of about 13 metres. The reservoir at Wraysbury, which will be fitted with the pumping system and which is due to come into service two years from now, will store 7,000 metric gallons on 340 acres. The largest of the board's existing reservoirs stores 6,500 metric gallons on 770 acres. The saving in land costs alone is estimated at $£ 1.7$ million, and there will be a comparable saving at the new reservoir being built at Datchet.

The trials of the pumping system which have been carried out at the King George VI reservoir have been impressive. Within five days during the summer of 1966 , the volume of usable water was increased by $6 \times 10^{6}$ cubic metres-almost a third of the capacity of the reservoir-by lifting water between 11 and 13 metres below the surface to $\mathbf{4 \cdot 6}$ metres below. The volume of usable water was increased at a rate of 14 cubic metres a second although the output of the pump was only one cubic metre a second, apparently because pumping creates conditions in which windwater energy interchange is effective at comparatively great depths.

The problem of stratification in reservoirs is not new, of course, and neither are attempts to break it by pumping. The secret of the board's success seems to be the efficiency of the pumping system. Water is discharged horizontally as jets a few metres below the surface and these entrain large volumes of surrounding water so as to ensure turbulent heat exchange. In the experiments at the King George VI reservoir, mixing occurred to a depth of one metre below the level of the pump discharge even though the pumps were designed to draw water only from radial positions. According to the board's 42nd annual report, the operating cost of the pumps is negligible.

Transfer of deoxygenated bottom water to the surface layers necessarily reduces their oxygen content, but surface re-aeration and photosynthetic algae rapidly restore the oxygen level to near saturation. By bringing deep water rich in minerals to the surface, there is the risk of inducing algal blooms. Thus, in the King George VI experiments, pumping resulted in a bloom of the diatom Asterionella formosa which normally blooms in the Thames valley in February and March - not in July-but the bloom died dramatically in August. In fact, the board considers that by controlling pumping operations, it can prevent microorganisms rendering the water unacceptable.

\section{New Fields to Conquer}

THe Radiobiological Laboratory of the Agricultural Research Council at Wantage is one of the few laboratories to have redirected much of its research from an area of decreasing importance. The laboratory was established in 1957 to investigate environmental radioactivity from fallout, but the decreased demand for surveys and for quantitative measurements of the amount of strontium-90 in milk has meant that more time and effort can be spent on nutritional relationships between soil and plants. The laboratory claims to work in close cooperation with the other institutes of the ARC - the Grassland Research Institute, the Weed Research Organization, the Plant Breeding 